\title{
Enhanced Content of IgG in Burkitt's Lymphoma Cells after Treatment with the Topoisomerase II Inhibitor, Lucanthone
}

Robert Bases $^{1 *}$, Rukmani Lekhraj ${ }^{2}$, Xudong Tang ${ }^{3}$, Jinghang Zhang ${ }^{3}$, Zhi Duan ${ }^{4}$, Jennifer T Aguilan ${ }^{5}$ and Edward Nieves ${ }^{6}$

${ }^{1}$ Departments of Radiology and Radiation Oncology, Albert Einstein College of Medicine, Montefiore Medical Center, NY 10467, USA

${ }^{2}$ Departments of Neurosurgery, Montefiore Medical Center, Bronx, NY 10467, USA

${ }^{3}$ Departments of Microbiology and Immunology, Albert Einstein College of Medicine, NY 10461, USA

${ }^{4}$ Departments of Cell Biology, Albert Einstein College of Medicine, Bronx, NY 10461, USA

${ }^{5}$ Departments of Pathology, Albert Einstein College of Medicine, Bronx, NY 10461, USA

${ }^{6}$ Departments of Biochemistry, Albert Einstein College of Medicine, Bronx, NY 10461, USA

\begin{abstract}
Burkitt's lymphoma cells (CRL-1647) which had survived treatment with lucanthone contained 3.6 fold more IgG than untreated cells, although most of the cellular immunoglobulins were still IgM. DNA activation induced cytidine deaminase (AID) was increased 5 fold in these surviving cells, consistent with active Class Switch Recombination (CSR).

Progeny of the small fraction of cells which had survived $20 \mathrm{~h}$ exposure to $8 \mu \mathrm{M}$ lucanthone before rescue were cloned. $1.5 \times 10^{8}$ cloned cells contained $\sim 1 \mu \mathrm{g}$ of cytidine DNA deaminase, as determined from affinity column isolation of the enzyme, assayed by digestion of a $30 \mathrm{nt}^{32} \mathrm{P}$ labeled specific DNA substrate. Before lucanthone treatment, little AID could be detected. After the second treatment, a six fold increase in AID was found. In confirmation, Western blot determinations of AID from lysates of lucanthone treated cells showed 5 fold increased AID content. These results suggest that lucanthone led to increased IgG content of surviving cells, consistent with their increased AID activity. The surviving cells were also more resistant to the standard lucanthone treatment, as determined in clonogenic assays.
\end{abstract}

IgG could not be detected in the cell membranes of CRL cells before or after lucanthone by immunostaining and flow cytometry, but both cell types secreted $80 \mathrm{kDa}$ and $25 \mathrm{kDa}$ immunorelated protein.

Lucanthone, formerly used to safely to treat hundreds of thousands of schistosomiasis patients, might be considered as a means to promote lgG synthesis in macroglobulinemia patients.

Keywords: Cytidine deaminases; Class Switch Recombination (CSR); Lucanthone; Clonogenic assay; Activation Induced Deoxycytidine deaminase (AID)

\section{Introduction}

The role of DNA Activation Induced Deoxycytidine deaminase (AID) in class switch recombination (CSR), i.e., switching from synthesis of IgM to IgG inlymphocytes, has been well established [1,2]. Furthermore, AID deficiency has been implicated in the hyper-IgM syndrome [3]. The proto oncogene, c-myc, which regulates antibody secretion, in significantly involved in CSR [4].

We considered ways to enhance CSR in Burkitt lymphoma cells, as a model to learn how to enhance CSR in clinical situations. AID deaminates DNA cytidines on single stranded DNA [5] leaving DNA uridines that are then removed by ubiquitous cellular uracil DNA glycosylases. Abasic sites and double strand breaks result, which may be essential for CSR. We sought to mimic the deamination step by treating Burkitt lymphoma cells with lucanthone, an inhibitor of topoisomerase II [6], whose ability to create Abasic sites and double strand breaks in DNA of HeLa cells had been demonstrated $[7,8]$. As a caveat, we note that DNA deamination activity of AID might not alone represent its physiological function $[9,10]$.

Burkitt lymphoma cells CRL-1647 synthesize IgM but little IgG. Here we describe experiments to learn if IgG synthesis was stably enhanced many generations after the lucanthone treatment of Burkitt lymphoma cells.

Continuous exposure to concentrations of $8 \mu \mathrm{M}$ lucanthone beyond 2-4 h progressively sterilized HeLa cells. This lethal effect must be taken into account in the results to be described here i.e., could the increase in IgG synthesis result from selection of a special cell population?

Lucanthone's effects on HeLa cells were readily reversible [11]. Furthermore, it has an unblemished clinical safety record [12]. It was given to hundreds of thousands of patients who were treated for schistosomiasis in the past. Currently, lucanthone is used clinically as an adjuvant to radiation therapy [13]. We encountered no hematologic toxicity or other toxicity when care was taken to avoid interference from concurrent medications. Lucanthone was well tolerated when administered to patients daily for several weeks, maintaining serum concentrations of $8 \mu \mathrm{M}$ lucanthone. The in vitro studies described here employed $8 \mu \mathrm{M}$ lucanthone. Lucanthone is promptly eliminated by the liver and kidneys in experimental animals. HeLa cells suffered no loss of clonogenic survival for $2 \mathrm{~h}$ in $8 \mu \mathrm{M}$ lucanthone when growth medium was then changed. But a thousand fold loss of survival was found if lucanthone removal was delayed $20 \mathrm{~h}$ [11]. Serum lucanthone

*Corresponding author: Robert Bases, Professor of Radiology and Radiation Oncology, Albert Einstein College of Medicine, Montefiore Medical Center, 111 East 210th Street, Moses Research Building, 301, Bronx, NY 10467, USA, Tel: 914-380-2757; Fax: 914-632-3056; E-mail: rbases@verizon.net

Received June 19, 2017; Accepted July 12, 2017; Published July 19, 2017

Citation: Bases R, Lekhraj R, Tang X, Zhang J, Duan Z, et al. (2017) Enhanced Content of IgG in Burkitt's Lymphoma Cells after Treatment with the Topoisomerase II Inhibitor, Lucanthone. J Bioanal Biomed 9: 186-193. doi:10.4172/1948593X.1000176

Copyright: $\odot 2017$ Bases R, et al. This is an open-access article distributed under the terms of the Creative Commons Attribution License, which permits unrestricted use, distribution, and reproduction in any medium, provided the original author and source are credited. 
concentrations of $8 \mu \mathrm{M}$ are readily achieved, and are well tolerated. The $8 \mu \mathrm{M}$ lucanthone in cell culture increased the frequency of DNA abasic sites and double strand DNA breaks [7,8]. A study of lucanthone concentration dependence would be of interest but is beyond the scope of this initial report. The Burkitt lymphoma cell line was chosen because it was a B cell line which contained IgM but little or no IgG, so that it was a good target for study.

\section{Materials and Methods}

\section{Cells}

CRL-1647 Burkitt human lymphoma cells (0L) were purchased from American Type Culture Collection (ATCC), Manassas, VA 20108. They were grown in suspension at $37^{\circ} \mathrm{C}$ in Roswell Park Memorial Institute 1640 medium with $10 \%$ fetal bovine serum in $8 \% \mathrm{CO}_{2}$ in a humidified atmosphere. The cell culture doubling time was $24 \mathrm{~h}$. Media and sera were from ATCC. After two serial treatments with lucanthone, the lymphoma cells are designated: $2 \mathrm{~L}$.

\section{Cell lysates}

Cells were sedimented from phosphate buffered saline without $\mathrm{Ca}^{++}$ or $\mathrm{Mg}^{++}$, resuspended in lysis buffer [14] with $10 \mu \mathrm{M}$ Aprotinin and sonicated with 20 one-second strokes, leaving 1-2\% unbroken cells. Lysates of $10^{7}$ to $10^{8}$ cells that were clarified by centrifugation at 15,500 $\mathrm{g}$ for $12 \mathrm{~min}$ contained approximately $1 \mu \mathrm{g} / \mu \mathrm{l}$ of protein [15].

\section{Western blots}

For most experiments, $7 \mathrm{~cm}$ mini gels, purchased from BioRad Laboratories, Los Angeles, CA were used. Buffer without SDS or methanol, containing $25 \mathrm{mM}$ Tris, $\mathrm{pH} 8.3$ and $192 \mathrm{mM}$ glycine were used for gel electrophoresis and Western blot transfer.

Detection of IgM and IgG in cell lysates was made in Western blots, using goat anti-human IgG pre-coupled to horseradish peroxidase (SC 2453) (Santa Cruz Biotechnology, Inc., Santa Cruz California, 95060).

This antibody reacts with IgM and more strongly with IgG. An advantage is that both IgG and IgM can be determined in the same cell lysate aliquot in the same gel lane. Quantitation is made by reference to immunodensities of reference standards in the gel. To characterize the relative abundance of $\operatorname{IgG}$ and $\operatorname{IgM}$ in an aliquot, relative immunodensities were determined: $\operatorname{IgG} /(\operatorname{IgG}+\operatorname{IgM})$. For untreated Burkitt lymphoma cells in this report the ratio was $0.20 \pm 0.05 \mathrm{SE}$, from 4 separate experiments. After transfer of immunoglobulins to nitrocellulose membranes and blocking with 5\% milk proteins, membranes were stained with antibody, rinsed, and immunofluorescence was induced with ECL reagent RPN2209 [GE Health Care, Amersham, Buckinghamshire.

[HP7 9NA, U.K] After exposure to x-ray film, gel band IgG and IgM were scored by densitometry. Complete transfer of proteins from gels to nitrocellulose membranes was verified by loading one lane of each gel with a mix of multicolored purified proteins encompassing the sizes of IgM and IgG (Kaleidoscope-BioRad). After transfer, bands were found in the membranes, none in the gels.

Human IgG, $11.2 \mathrm{mg} / \mathrm{ml}$ was bought from Pierce Biotechnology Rockford Illinois, product \#31154. Human IgM (myeloma), $4.5 \mathrm{mg} / \mathrm{ml}$, product 31146 was from (Pierce).

Actin was determined in cell lysates by electrophoresis in tris glycine mini gels and transfer to nitrocellulose membranes. The actin bands were stained first with mouse anti actin (Cal Biochem mAb, JLA
$20 \mathrm{CAT} \# \mathrm{CP} 01)$ at 1:5000 dilution for $2 \mathrm{~h}$ followed by goat anti-mouse IgM pre-coupled to horse radish peroxidase (JA 1200) at 1:2000 dilution for $2 \mathrm{~h}$. Immunofluorescence then was induced by the ECL reagent and bands detected by exposure to X-ray film were scored by densitometry. Cell lysates had been prepared without mercaptoethanol, to prevent interference with IgM. Because of this, actin aggregates species were encountered in the gel lanes. Their sizes were from $\sim 10^{5} \mathrm{MW}$ to $\sim 10^{6}$ MW. Therefore, the densities of all the actin reactive species in each lane were determined together.

\section{Nucleic acid gel electrophoresis assay for AID}

A single stranded substrate 30 nt DNA, TTT TTT TTT TTT TTA GCA TTT TTT TTT TTT, was purchased from Life Technologies, InVitrogen Carlsbad, CA 920081. 5' 32P end labeling was accomplished with T4 polynucleotide kinase from InVitrogen according to the manufacturer's instructions, using 5 pmol of substrate and $25 \mu \mathrm{Ci}$ of [ $\gamma$ 32P] ATP, $3000 \mathrm{Ci} / \mathrm{mmol}$, Perkin Elmer, Shelton, CT 06484. After labeling, the reaction was stopped by addition of EDTA to $5 \mathrm{mM}$ and incubation at $65^{\circ} \mathrm{C}$ for $5 \mathrm{~min}$. The $30 \mathrm{nt}$ long labeled product was purified by centrifugation through a Micro Bio spin 6 column, BioRad, to remove smaller species [5].

Enzyme activity was measured by cleavage at the single cytidine, which released $32 \mathrm{P}$ labeled $16 \mathrm{nt}$ product, accompanied by undigested $30 \mathrm{nt}$ substrate. Usually, $10 \mu \mathrm{L}$ reaction mixtures containing $0.5 \mathrm{pmol}$ of 32P labeled substrate in $10 \mathrm{mM}$ Tris- $\mathrm{HCl} \mathrm{pH} 8.0,1 \mathrm{mM}$ EDTA and 1 mM DTT were incubated with $5 \mu \mathrm{L}$ of sample at $37^{\circ} \mathrm{C}$ for $15 \mathrm{~min}$. Cell lysates were pretreated by digestion with $10 \mu \mathrm{g} / \mathrm{ml}$ of pancreatic RNase for $30 \mathrm{~min}$ at $37^{\circ} \mathrm{C}$.

Uracil DNA glycosylase, $1 \mu \mathrm{L}$ ( 1 unit/ $\mu \mathrm{L})$, InVitrogen, was added, followed by $15 \mathrm{~min}$ of incubation at $37^{\circ} \mathrm{C}$ to remove uracil products of AID digestion. The resulting abasic sites were cleaved by adding $1 \mu \mathrm{L}$ of $2 \mathrm{~N} \mathrm{NaOH}$ to the reaction mixture and heating for $5 \mathrm{~min}$ at $95^{\circ} \mathrm{C}$. Then $10 \mu \mathrm{L}$ of formamide were added.

After these additions, 10-15 $\mu \mathrm{L}$ of TBE sample buffer (BioRad, 1610768), were added and the samples were placed in the $30 \mu \mathrm{L}$ sample wells of $15 \%$ acrylamide TBE urea gels (BioRad 161 _ 1117). After electrophoresis for 60-75 min, the gels were exposed to $\mathrm{x}$ ray film for $60 \mathrm{~min}$ or more. The radioautograms were scanned by quantitative densitometry. Radiographic densities of faster migrating 16 nt DNA enzyme lysis products were quantitated and expressed as fractions of the sum of residual $30 \mathrm{nt}$ substrate and $16 \mathrm{nt}$ product densities.

\section{Oligodeoxycytidylic affinity column purification of AID}

$1 \mathrm{ml}$ HiTrap affinity columns (GE Health Care, Biosciences, Uppsala, Sweden SE 75184) were first prepared by binding oligodexoxy cytidine (American Biosciences, Piscataway, NJ 08855) according to the manufacturer's directions. We expected that few of the primary amino groups of the polydeoxycytidylic would be eliminated by the binding step at $4^{\circ} \mathrm{C} ; 600 \mu \mathrm{g}$ of oligo $\mathrm{dC}$ were bound to the column. Cell lysates from $1.5 \times 10^{8}$ cells were introduced for binding at $4^{\circ} \mathrm{C}$ and after 125 min, the column was washed at $4^{\circ} \mathrm{C}$ to eliminate unbound AID and other proteins. The column was kept in Phosphate Buffered Saline (PBS) at $4^{\circ} \mathrm{C}$ to prevent cytidine deaminase digestion of the column bound cytidylic amino groups.

To release cytidine deaminases from the column, elutions were made with $0.5 \mathrm{ml}$ of $0.2 \mathrm{~N} \mathrm{NaCl}$ in $0.04 \mathrm{M}$ Glycine at $\mathrm{pH} 3.0$ and then $0.5 \mathrm{ml}$ of $0.5 \mathrm{~N} \mathrm{NaCl}$ in $0.1 \mathrm{M}$ Glycine at $\mathrm{pH} 3.0$, followed by PBS. 5.0 $\mu \mathrm{L}$ aliquots of each $500 \mu \mathrm{L}$ column fraction were assayed for cytidine deaminases. 
Purified AID was purchased from Enzymax, Lexington, KY 40503.

\section{In-gel trypsin digestion}

Excised gel bands were reduced with $10 \mathrm{mM}$ TCEP (tris-carboxyethylphosphine, Sigma, USA), alkylated with $55 \mathrm{mM}$ iodoacetamide (Sigma, USA) and digested with trypsin (Trypsin Gold, Promega, USA) in $25 \mathrm{mM}$ ammonium bicarbonate $\mathrm{pH}=8$ (Sigma, USA), $0.01 \%$ ProteaseMax (Promega, USA) at $50^{\circ} \mathrm{C}$ for $1 \mathrm{~h}$.

\section{Mass spectrometry analysis}

LC-ESI-MS/MS (liquid chromatography electrospray ionization mass spectrometry) analysis of the peptide digests was done by C18-Reversed Phase (RP) chromatography using an Ultimate 3000 RSLCnano System (ThermoScientific, USA) equipped with an Acclaim PepMap RSLC C18 column $(2 \mu \mathrm{m}, 100 \AA$ A, $75 \mu \mathrm{m} \times 15 \mathrm{~cm}$, Thermo Scientific, USA). The UPLC was connected to a TriVersa NanoMate nanoelectrospray source (Advion, USA) and a linear ion trap LTQ-XL (ThermoScientific, USA) mass spectrometer with ESI source operated in the positive ionization mode. The MGF files generated from the raw LC-ESI-MS/MS data were searched by Mascot (version 2.5, Matrix Science, USA) against Swissprot AC database version 2016-05 (551,193 protein sequences) with the following search parameters: trypsin; two missed cleavages; peptide charges of +2 and +3 ; peptide tolerance of $2.5 \mathrm{Da}$; MS/MS tolerance of $0.8 \mathrm{Da}$; Carbamidomethylation (Cys) for fixed modification; deamidation (Asn and Gln) and oxidation (Met) for variable modifications. A decoy database search was also performed to measure false discovery rate. The Mascot search results were validated by Scaffold version 4.1.1 (Proteome Software Inc., USA).

\section{Results}

\section{Lucanthone treated cells contain more IgG}

Goat antihuman IgG reacts with both IgG and IgM. IgG was much more reactive, as noted in the legend for Figure 1A. For ease of comparison we scored both their immunoreactivities. Estimates were also made of protein content in gel bands, by reference to standard IgM and IgG gel band protein contents. Figure 1A and Figure 1B clearly show that lymphoma cells which survived lucanthone $1 \mathrm{~L}$ contained 3.6 times more IgG (by relative immunofluorescence) than untreated cells (0L). Furthermore, when estimated from protein content without lucanthone treatment, IgM was 398 times more abundant; after lucanthone treatment, IgM was 53 times more abundant indicating increase in relative $\operatorname{IgG}$ abundance.

Figure 1B shows results of determinations made in another experiment with a CRL-1647 cell lysates. Enhancement of IgG was again found in the cells from this culture, which also had grown from cells which survived treatment with $8 \mu \mathrm{M}$ lucanthone. From these 2 experiments we found that lucanthone survivors of one lucanthone exposure contained 3.6 fold enrichment of IgG, determined from Western blots of Figure $1 \mathrm{~A}$ and $1 \mathrm{~B} ; \mathrm{p} \leq 0.01$. Survivors of a second lucanthone exposure exhibited a small increase in $\operatorname{IgG} /(\operatorname{IgG}+\operatorname{IgM})$.

In an experiment (not shown) the ratio for $1 \times$ lucanthone survivors was $0.75 \pm 0.0067 \mathrm{SE}$; for the $2 \times$ lucanthone survivors it was $0.85 \pm 0.010 \mathrm{SE}$, the difference was significant, $\mathrm{p}<0.001$. In 5 separate experiments with survivors of one lucanthone treatment, the $\mathrm{IgG} /$ $\operatorname{IgG}+\operatorname{IgM}$ was $0.57 \pm 0.09 \mathrm{SE}$, significantly different from results with 4 separate experiments with untreated cells $(0.20+-0.05 \mathrm{SE})$ at $\mathrm{p}>-0.01$.

Determination of enhanced content of IgG in cell lysates

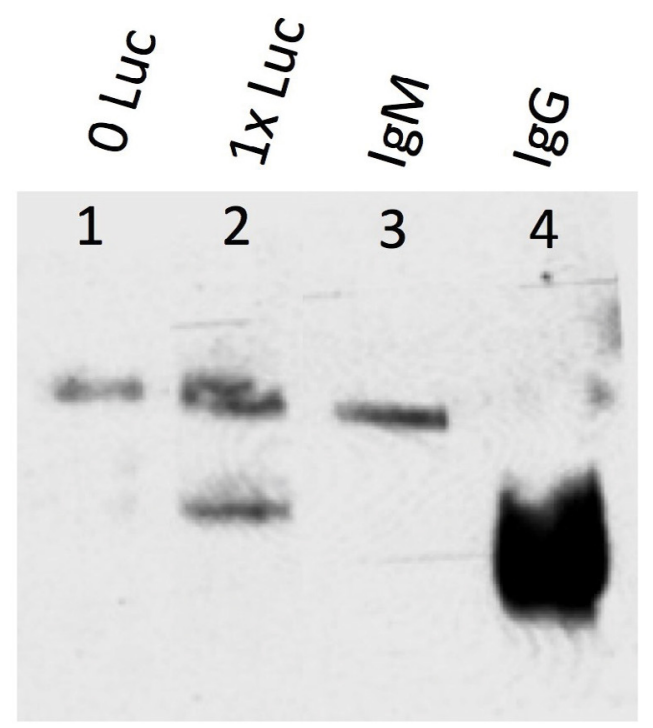

Figure 1A: Treatment of the Burkitt lymphoma cells with $8 \mu \mathrm{M}$ lucanthone for 18 hours, followed by recovery in normal growth medium for 22 days; the relative abundance of cellular IgG was increased in cell lysates. Lane 1: no lucanthone; lane 2: $8 \mu \mathrm{M}$ lucanthone; lane $3: \operatorname{lgM} 4.5 \mathrm{ng}$; lane $4: \operatorname{lgG}$. $1.1 \mathrm{ng}$. Relative immunoreactivity of $\mathrm{lgG} /(\lg \mathrm{M}+\lg \mathrm{g})$ increased from 0.075 to 0.32 . Input to lane 1-lysate from $1.2 \times 10^{5}$ cells. Input to lane 2 lysate from 3 $\times 10^{5}$ cells. Determination of immune protein content in lysates was made by comparing their IgG and IgM gel band densities with their standards. Without lucanthone treatment, 107 cells contained $0.42 \mathrm{ng} \operatorname{lgG}$ and $167 \mathrm{ng}$ IgM. After lucanthone, 107 surviving progeny contained $4.6 \mathrm{ng}$ lgG and $242 \mathrm{ng} \operatorname{lgM}$.

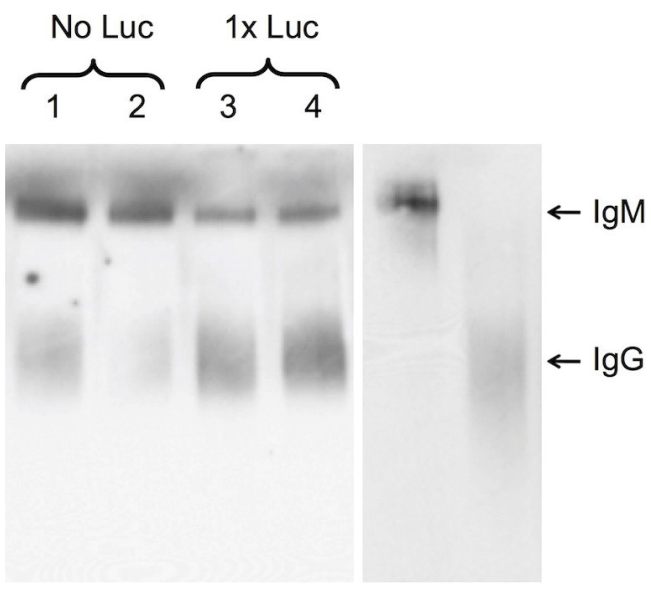

Figure 1B: Treatment of Burkitt lymphoma cells with $8 \mu \mathrm{M}$ lucanthone for $24 \mathrm{~h}$ followed by recovery for 24 days in normal growth medium. The relative abundance of cellular IgG was increased in cell lysates. Lanes 1 and 2: No lucanthone. Input to lanes: Lysates from $2 \times 10^{5}$ cells. Relative immunoreactivity: $\lg \mathrm{G} /(\lg \mathrm{G}+\operatorname{lgM}) 0.18$ and 0.10 . Lanes 3 and 4 : Lucanthone, $8 \mu \mathrm{M}$ for $24 \mathrm{~h}$, followed by recovery. Input to lanes: Lysates from $2 \times 10^{5}$ cells. Relative immunoreactivity $\operatorname{lgG} /(\lg G+\operatorname{lgM}) 0.46$ and 0.50 . Lanes $1-4$ : 2 min ECL exposure. IgM and IgG standards were from $5 \mathrm{~s}$ ECL exposures of the gel.

in individual lanes did not depend upon comparisons between individual lanes.

The actin content of lysates of Figure 1B as well as lysate from cells which had survived two lucanthone treatments ( $2 \mathrm{~L}$ cells) was compared in Figure 1C. Lucanthone survivor's actin content was two to three 


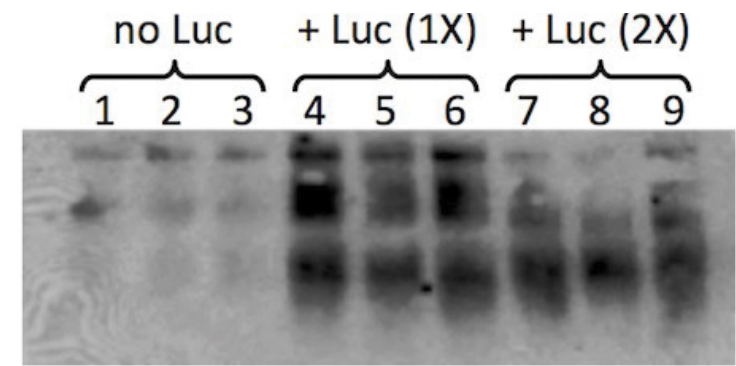

Figure 1C: The aggregate actin related densities from cell lysates were scored. Cell lysates had not been treated with heat and dithiothreitol before electrophoresis, resulting in several actin positive bands over a range of sizes. The range of sizes from $2 \times 10^{5}$ to $8.3 \times 10^{4}$. Actin content of the cells in the study of Figure 1B was compared by immunofluorescence, as described in the Methods section. Lysates from $2 \times 10^{5}$ cells of each of the three groups were compared. Lanes 1, 2, 3-No lucanthone; relative immunodensities: 955, 859, 1117, mean: 977. Lanes 4, 5, 6-Lucanthone survivors; relative immunodensities: 2776, 2442, 2777, mean: 2665 . Lanes 7, 8, 9-2 times lucanthone treatments; relative immunodensities: 2326, 2001, 2487, mean: 2272.

folds greater than obtained with untreated cells, over a wide range of molecular sizes. Determination of their post lucanthone enhanced IgG was not related to actin content (Figure 1C); both IgG and IgM in each lane were normalized by the same factor.

ELISA assays for the four IgG isotypes in $0 \mathrm{~L}$ and $2 \mathrm{~L}$ cells' lysates show enrichment of the four isotypes in $2 \mathrm{~L}$ cells, confirming in 4 separate assays, the determinations made by Western blots previously (Figure 2).

We eliminated the possibility that $\operatorname{IgG}$ isotypes had been absorbed to $2 \mathrm{~L}$ cells from the fetal bovine serum in growth medium. Testing the serum by ELISA assays failed to detect such antigenicity (not shown). Because all four IgG isotypes were involved, RT PCR studies would probably not be helpful.

\section{Aid is enhanced in lucanthone survivors}

Single cell survivors of $8 \mu \mathrm{M}$ lucanthone were cloned by terminal dilution in a 96 well plate. One clone, A-7, was grown and tested for IgM and IgG by relative fluorescence. As expected, IgG cell content was enhanced, as measured by immunofluorescence, to 0.49 and 0.36 in the uncloned and cloned cells (not shown).

To learn if cytidine DNA deaminase was present in A-7 cells, cell lysates were purified by binding to polydeoxycytidine containing column and eluting, as described in Materials and Methods. Three major fractions contained enzyme activity (Figure 3).

Previously, two major fractions were found when bone fide AID was analyzed on a similar column [16]. AID activity of these 2L cells was increased (Figure 4). AID from $3 / 8$ as many cells assayed in the experiment of Figure 3 yielded 2.5 fold more AID in the experiment of Figure 4, comparing the areas under the elution curves of Figures 3 and 4. Therefore, an overall six fold increase in AID activity was achieved. Untreated lymphoma cells contained little detectable AID activity (Figure 4).

Western blot analyses in Figure 5 showed that AID in 2L cells was 5.4 fold more abundant than in $0 \mathrm{~L}$ cells, as expected from previous results shown in Figures 3 and 4.

Western blot determination of AID from 0L and 2L cells (Figure 5)
IgG concentration

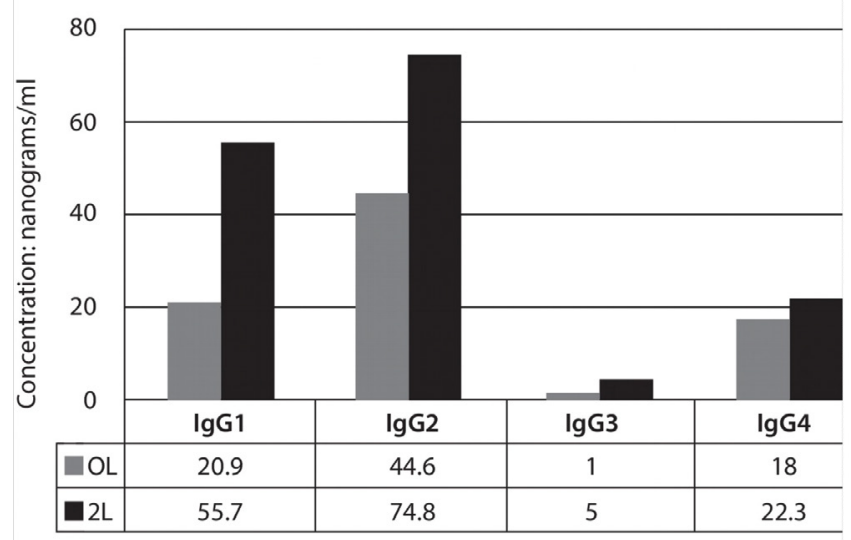

Figure 2: Legend for ELISA assay of $0 \mathrm{~L} / 2 \mathrm{~L}$ cells. Lysates were prepared by sonication of $1.5 \times 10^{8} \mathrm{OL}$ cells and $2.0 \times 10^{8} 2 \mathrm{~L}$ cells; supernatants were harvested after centrifugation at $12,365 \mathrm{~g}$ for $16 \mathrm{~min}$. Equal concentrations of the four isotypes of IgG were compared by ELISA assays, as shown in Figure 2 , using reagents from Life Technologies ref 991000.

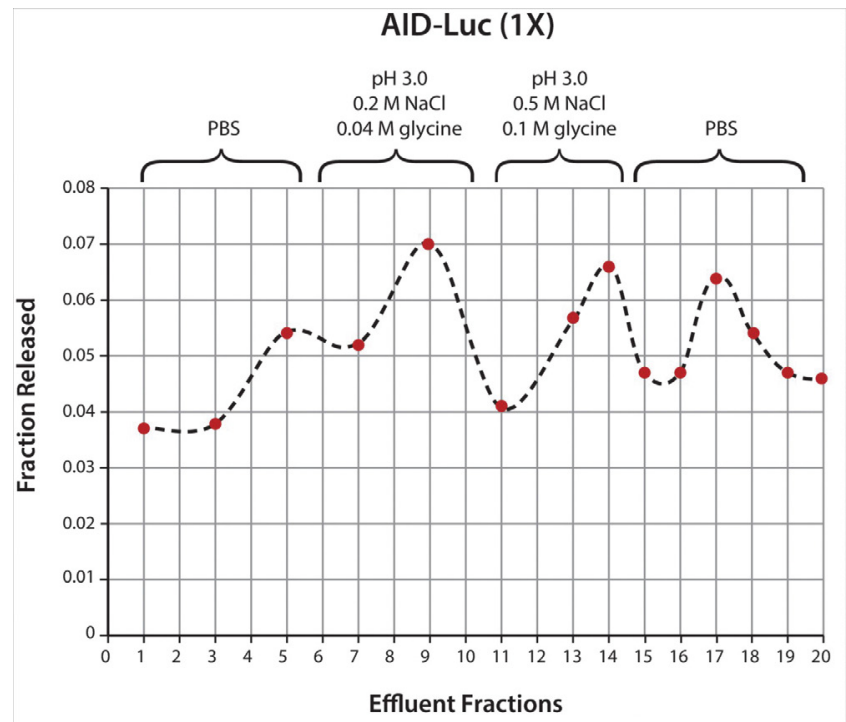

Figure 3: Binding and release of cellular deoxycytidine deaminase from an affinity column containing $\sim 600 \mu \mathrm{g}$ of bound $100 \mathrm{nt}$ long polydeoxy cytidine oligomers. $1.5 \times 10^{8} \mathrm{CRL}-1647\left(\mathrm{~A}^{-7}\right)$ cells cloned after $18 \mathrm{~h}$ treatment with $8 \mu \mathrm{M}$ lucanthone were sonicated and then sedimented at $12,365 \mathrm{~g}$ for 16 $\mathrm{min}$. Supernatants were treated with $10 \mu \mathrm{g} / \mathrm{ml}$ of DNAase free pancreatic ribonuclease and then bound to the column for $125 \mathrm{~min}$ at $0^{\circ} \mathrm{C}$. Serial elutions were made with phosphate buffered saline; $0.2 \mathrm{~N} \mathrm{NaCl}$ in $0.04 \mathrm{M}$ glycine $\mathrm{pH}$ $3.0 ; 0.5 \mathrm{~N} \mathrm{NaCl}$ in $0.1 \mathrm{M}$ glycine, $\mathrm{pH} 3.0$ and finally with phosphate buffered saline. $0.5 \mathrm{ml}$ fractions were collected. Enzyme activity in the fractions was determined by measuring release of $16 \mathrm{nt}{ }^{32} \mathrm{P}$ labeled DNA fragments from ${ }^{32} \mathrm{P}$ labeled $30 \mathrm{nt}$ DNA substrate. Release is expressed as the fraction of 30 nt DNA released as 16 nt DNA product, determined from autoradiographs of each gel lane $(\bullet-\bullet)$

showed that from $2.4 \times 10^{6} 0 \mathrm{~L}$ cells $0.025 \pm 0.011$ micrograms were found; from $2.4 \times 10^{6} 2 \mathrm{~L}$ cells $0.13 \pm 0.025 \mu \mathrm{g}$ were found, indicating a 5.4 fold increase in AID in the lucanthone treated cells. A confirming experiment (Figure 6) showed that normalizing for actin content in $0 \mathrm{~L}$ and $2 \mathrm{~L}$ lysates indicated 7.7 fold increases in AID. 
Citation: Bases R, Lekhraj R, Tang X, Zhang J, Duan Z, et al. (2017) Enhanced Content of IgG in Burkitt's Lymphoma Cells after Treatment with the Topoisomerase II Inhibitor, Lucanthone. J Bioanal Biomed 9: 186-193. doi:10.4172/1948-593X.1000176

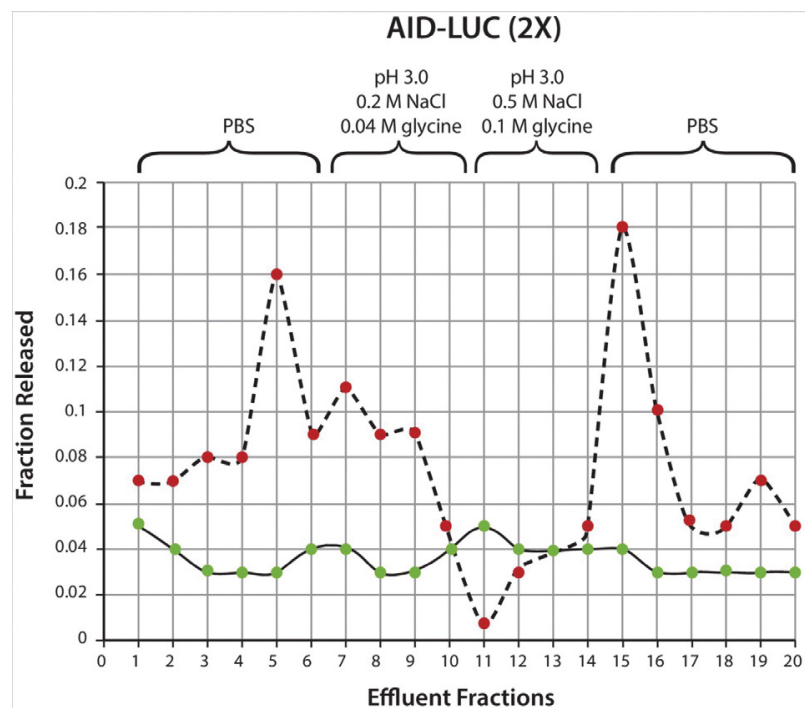

Figure 4: AID from $4 \times 10^{7}$ cells which had survived the second serial treatment with $8 \mu \mathrm{M}$ lucanthone was determined by elution from the polydeoxycytidine column, as described for Figure $3(\bullet-\bullet)$. Little or no AID activity was recovered in a lysate from 3.4 $\times 10^{7}$ untreated CRL-1647 lymphoma cells $(\bullet-\bullet)$

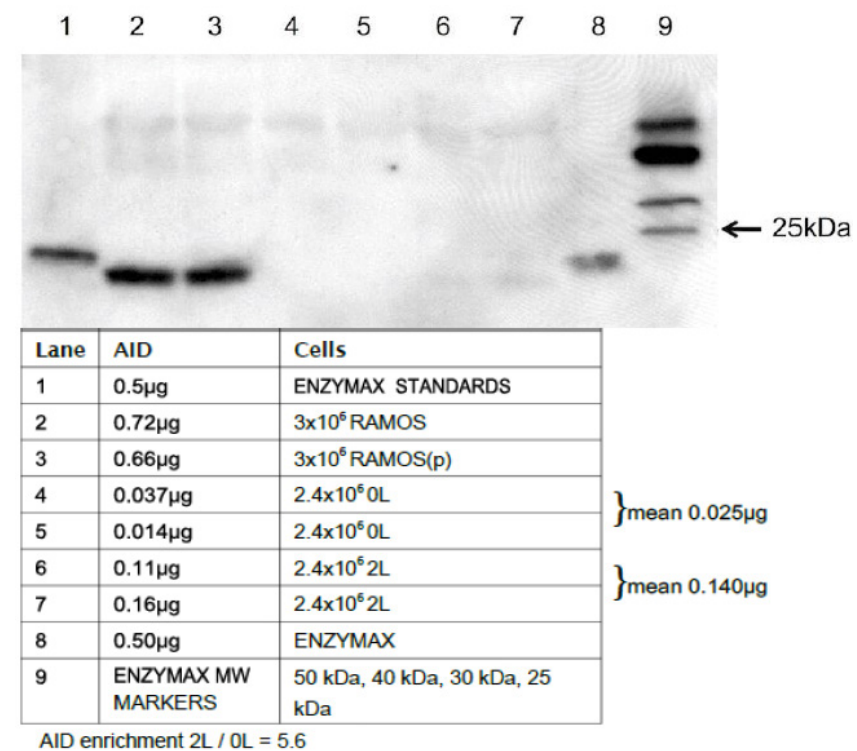

Figure 5: AID from $0 \mathrm{~L}$ cells and $2 \mathrm{~L}$ cells were determined from immunodensities in Western blots using rat mAB \#49595 (Cell Signaling).

Actin content of $0 \mathrm{~L}$ and $2 \mathrm{~L}$ cells was much greater than in Ramos cells. Ramos cells' AID content was four fold greater than the AID content of 2L cells, but elevated IgG was not found in Ramos cell survivors of lucanthone treatment and little or none.

IgG was found in untreated Ramos cells (not shown). Despite the AID activity in Ramos cells, IgG enhancement was not observed. So far, we have not been able to induce (or select) for cells with enhanced IgG content in Ramos 6.4 human Burkitt lymphoma cells or in a transplantable mouse lymphoma MOPC 460d (a kind gift of Dr. Michael Potter, National Cancer Institute, USA).

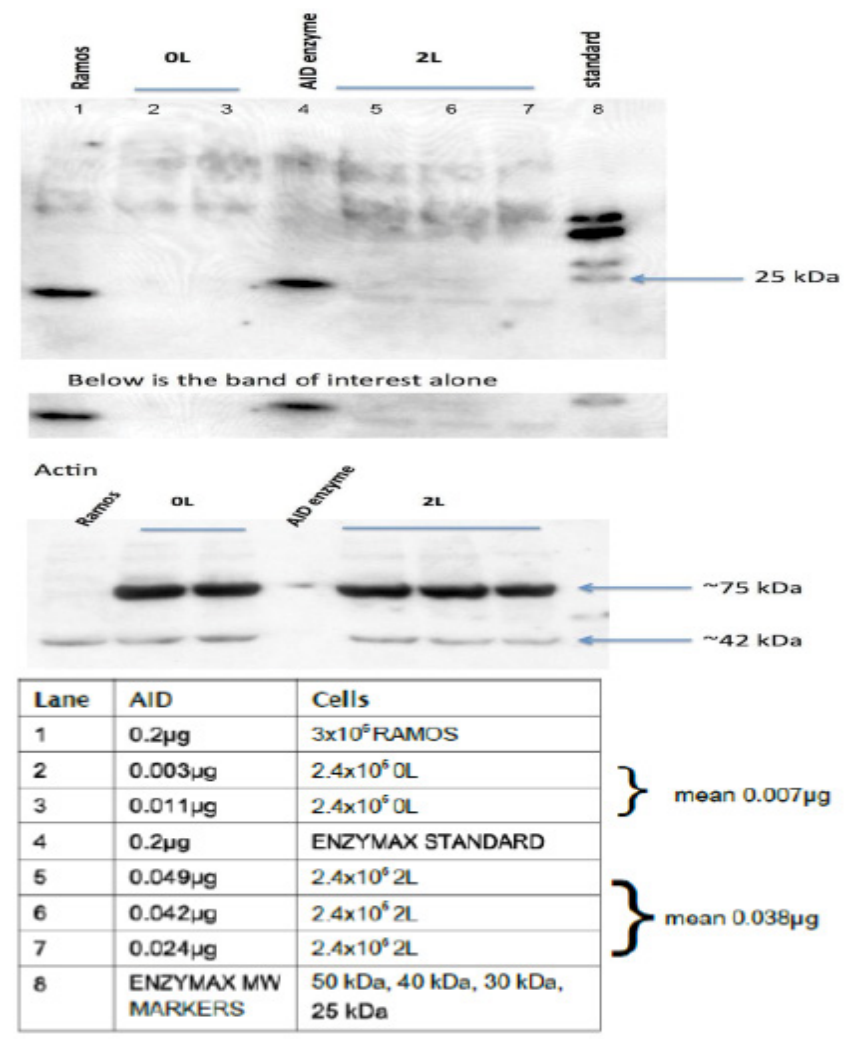

AID enrichment $2 \mathrm{~L} / 0 \mathrm{~L}=5.4$, corrected to 7.7 ; $0 \mathrm{~L}$ cells $7 \mathrm{ng}, 2 \mathrm{~L}$ cells $38 \mathrm{ng}$; From $3 \times 10^{6}$ Ramos cells $200 \mathrm{ng}$ were obtained; Antibodies were stripped from the nitrocellulose membrane, and it was restrained with mouse anti actin, followed by horseradish peroxidase labeled goat anti-mouse antibodies; AID density/ actin density at $42 \mathrm{kDa}, 20 / 628,75 / 717$ for OL cells; AID density/actin density at $42 \mathrm{kDa} 346 / 645,295 / 515,170 / 395$ for $2 \mathrm{~L}$ cells; OL Normalized AID is 0.066 ; $2 \mathrm{~L}$ Normalized AID is 0.51 . Therefore, $0.51 / 0.066=7.7$ fold increase in AID in $2 \mathrm{~L}$ cells; For $8 \times 10^{6}$ Ramos cells, 1349 AID Units found

Figure 6: AID from $2.4 \times 10^{6} 2 \mathrm{~L}$ cells and $2.4 \times 10^{6} \mathrm{OL}$ cells were determined, comparing the immunodensities in Western Blots using rat mAb \#49595 from Cell Signaling Technology and bone fide AID from Enzymax.

\section{Resistance of lucanthone survivors to retreatment, determined by clonogenic assays in polyornithine coated plastic dishes}

Normally CRL-1647 lymphoma cells grow in suspension and do not attach to plastic surfaces. To evaluate their clonogenic fraction, plastic dishes were first coated with polyornithine [17]. Macroscopic colonies were counted in single-cell assays after 12 days of incubation. Parallel studies of growth in uncoated 96 well plastic plates, after terminal dilution confirmed the clonogenic fractions were the same. The clonogenic fraction of $0 \mathrm{~L}$ cells was $0.097 \pm 0.03 \mathrm{SE}$. After recovery, the clonogenic fraction of log phase survivors of one or two lucanthone challenges [ $20 \mathrm{~h}$ in $8 \mu \mathrm{M}$ lucanthone], were 0.18 and 0.11 , respectively.

By contrast, when these cell cultures were challenged by $8 \mu \mathrm{M}$ lucanthone for $20 \mathrm{~h}$ and immediately tested, the clonogenic fraction of naive cells was $1.5 \times 10^{-4} \pm 0.7 \times 10^{-4}$, but for the survivors of the one or two serial exposures to lucanthone the clonogenic fractions were $1.3 \times 10^{-3}$ and $2.9 \times 10^{-3}$. Lucanthone survivors were therefore tenfold more resistant to the standard challenge. They also exhibited enhanced AID content (Figures 5 and 6). These findings are compatible with selection of lucanthone resistant cells with enhanced $\operatorname{IgG}$ content and AID content. 


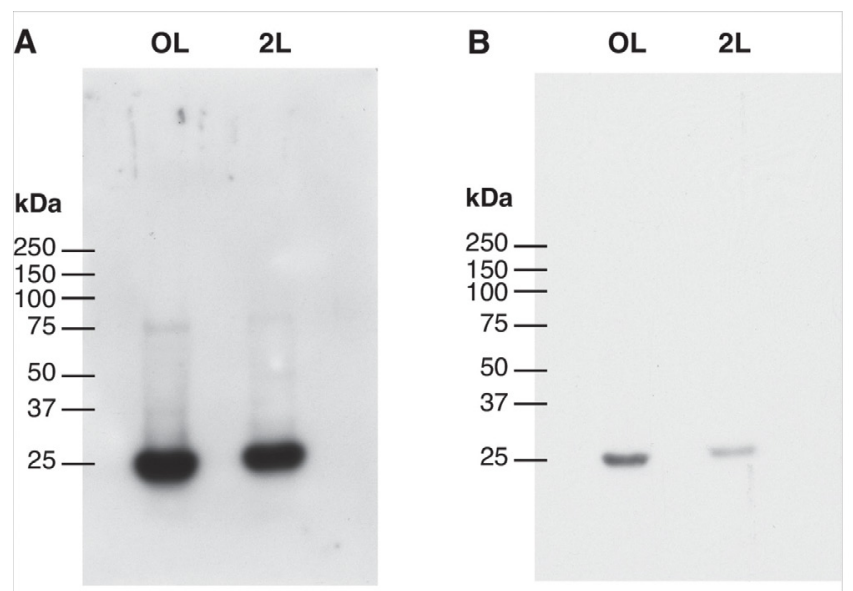

Figure 7: (A) $\mathrm{OL}$ cells and $2 \mathrm{~L}$ cells in the log phase growth were re-suspended in medium RPMI 1640 without serum at $2.4 \times 10^{6} / \mathrm{ml}$. After incubation at $37^{\circ} \mathrm{C}$ in $5 \% \mathrm{CO}_{2}$ for $6 \mathrm{~h}, 200 \mathrm{ml}$ of cell free supernatant were concentrated 2,000fold by membrane filtration (10 kDa MWCO). Two aliquots of $15 \mu \mathrm{l}$ each of the concentrated $\mathrm{OL}(293 \mu \mathrm{g})$ and $2 \mathrm{~L}(298 \mu \mathrm{g})$ were subjected to 1D-SDSPAGE. One replicate gel was used for Western blot analysis while the second replicate gel was stained with Coomassie and used for mass spectrometry analysis. Western blot analysis showed 80 and $25 \mathrm{kDa}$ protein bands were immunoreactive with goat anti-human $\mathrm{lgG} / \mathrm{lgM}$ antibody conjugated to horseradish peroxidase. Protein identification of the 80 and $25 \mathrm{kDa}$ gel bands was performed by in-gel trypsin digestion and peptide digests were analyzed by LC-ESI- MS/MS. Western blot $80 \mathrm{kDa}$ Ig from the $2 \mathrm{~L}$ cells were scanned; 9.0 density units were determined after 30 minutes exposure. With OL cells 17.3 density units were found. So far, absolute amounts of Ig gel proteins cannot be determined because structures and specific immunoreactivity of the 80 and 25 $\mathrm{kDa}$ proteins have not yet been determined. Nevertheless, results here are in agreement with previous results from mass spectrometry noted for the lg mu chain $\mathrm{C}$ region. (B) A 30 second exposure of the Western blot of Figure 8A was made to reduce the intensity of the $25 \mathrm{kDa}$ immuno proteins. For the $25 \mathrm{kDa}$ proteins from $2 \mathrm{~L}$ cells 25.2 density units were found; for OL cells 70.9 density units were found. Therefore, the $25 \mathrm{kDa}$ immunoproteins from $\mathrm{OL}$ cells were nearly three times as abundant secreted immunoproteins. Nevertheless, $2 \mathrm{~L}$ Ig kappa chains secreted were 1.4 times more abundant than OL kappa chains, previously noted.

Despite much effort, we failed to detect IgG on or in the cell membranes of $0 \mathrm{~L}$ cells and $2 \mathrm{~L}$ cells by immuno-flow cytometry. Nevertheless, we found that both cell types continuously released IgG and IgM immunorelated 80 and $25 \mathrm{kDa}$ species into their cell culture fluids (Figures 7 and 8 ). Secreted Ig related proteins were characterized by LC-ESI MS/MS.

\section{Quantitation of the $\sim 80 \mathrm{kda}$ and $\sim 25 \mathrm{kda}$ bands from $0 \mathrm{~L}$ and 2L supernatants}

$0 \mathrm{~L}$ and $2 \mathrm{~L}$ cells in the $\log$ phase growth were re-suspended in medium RPMI 1640 without serum at $2.4 \times 10^{6} / \mathrm{ml}$. After incubation at $37^{\circ} \mathrm{C}$ in $5 \% \mathrm{CO}_{2}$ for $6 \mathrm{~h}, 200 \mathrm{ml}$ of cell free supernatant were concentrated 2,000-fold by membrane filtration ( $10 \mathrm{kDa}$ MWCO). The concentrated supernatants $0 \mathrm{~L}(298 \mu \mathrm{g})$ and $2 \mathrm{~L}(293 \mu \mathrm{g})$ were also loaded on a gel and analyzed by Western blot and probed with SC 2453 antibody against immunoglobulin chains. The intensities of the bands from the immunoreactive Ig mu heavy chain $(\sim 80 \mathrm{kDa})$ and kappa light chains $(\sim 25 \mathrm{kDa})$ detected by Western blot (Figures $7 \mathrm{~A}$ and $7 \mathrm{~B}$ ) were quantified using Image to estimate the ratios of these two immuno-related proteins from the $\mathrm{OL}$ and $2 \mathrm{~L}$ supernatants. Quantitation of the $\sim 80 \mathrm{kDa}$ Ig mu chain was based on a 30 min exposure, $0 \mathrm{~L}$ was $2 \times$ higher compared to $2 \mathrm{~L}$. For the $\sim 25 \mathrm{kDa}$ kappa light chains, since the bands at $30 \mathrm{~min}$ exposure appeared to be overexposed, a more reliable quantitation was

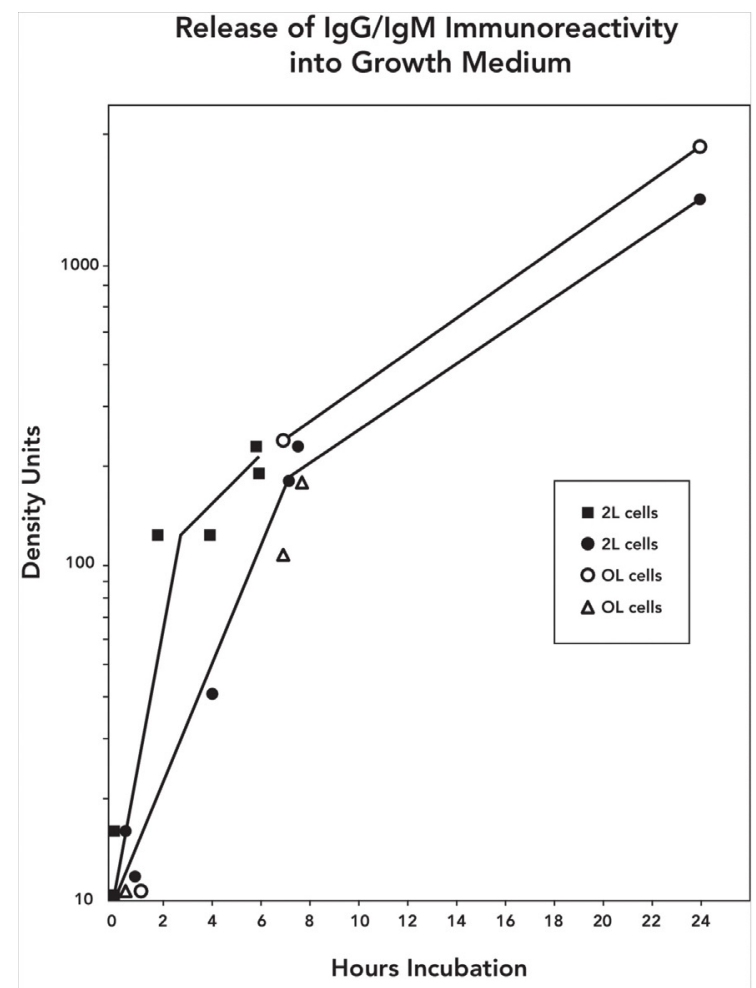

Figure 8: Time course of release of $\mathrm{lgG} / \mathrm{lgM}$ immunoreactivity into growth medium of $\mathrm{OL}$ and $2 \mathrm{~L}$ cell cultures. Western blot assays for $\mathrm{lgG} /$ IgM immunoreactivity were made on cell free supernatants from $\mathrm{OL}$ and $2 \mathrm{~L}$ lymphoma cell cultured at $2.4 \times 10^{6}$ cells $/ \mathrm{ml}$ in RPMI 1640 with $10 \%$ fetal bovine serum. Cell supernatants were sedimented at $10^{3} \mathrm{~g}$ for $2 \mathrm{~min}$ to eliminate cells before assays. Samples were heated at $100^{\circ} \mathrm{C}$ for $5 \mathrm{~min}$ in dithiothreitol, cooled and placed on mini gels for electrophoresis without SDS. $15 \mu \mathrm{L}$ of cell free supernatants were loaded on each gel lane. Comparison of the $\sim 80 \mathrm{kDa}$ densities from $\mathrm{OL}$ and $2 \mathrm{~L}$ cells with authentic IgG standards in the gel. One $\mathrm{ml}$ of the $2 \mathrm{~L}$ cells released $240 \mathrm{ng}$ of $\mathrm{lgG} / \mathrm{lg}$ immunoreactive proteins, assuming that the $80 \mathrm{kDa}$ species possess characteristics similar to those of $\operatorname{lgG}$, as yet unknown.

obtained based on the $30 \mathrm{~s}$ exposure. $0 \mathrm{~L}$ is $3 \times$ higher compared to $2 \mathrm{~L}$ for the $\sim 25 \mathrm{kDa}$ kappa light chains.

\section{Protein identification by LC-ESI-MS/MS}

Based on $99 \%$ protein and $95 \%$ peptide probabilities and a minimum of 2 unique peptides, a total 122 proteins were identified from both the 80 and $25 \mathrm{kDa}$ bands. Three immunorelated proteins were identified for both $\mathrm{OL}$ and $2 \mathrm{~L}$ cells. The Ig mu chain $\mathrm{C}$ region was identified from the $80 \mathrm{kDa}$ gel band while both the Ig kappa chain $\mathrm{C}$ region and Ig kappa chain V-II region were identified for the $25 \mathrm{kDa}$ gel band.

Label free quantitation based on normalized emPAI values (exponentially modified Protein Abundance Index) was used to estimate the ratios of immuno-related proteins identified for $0 \mathrm{~L}$ and $2 \mathrm{~L}$ cells. The Ig mu chain $\mathrm{C}$ region from $0 \mathrm{~L}$ cells was 0.69 while Ig mu chain $\mathrm{C}$ region from $2 \mathrm{~L}$ cells was 0.31 . Hence, $0 \mathrm{~L}$ was $2 \times$ higher compared to $2 \mathrm{~L}$ cells for the Ig mu chain $\mathrm{C}$ region. The normalized emPAI values for both Ig kappa chain C and V-II for the 0L cells was 0.84 while Ig kappa chain $\mathrm{C}$ and V-II for the $2 \mathrm{~L}$ cells was 1.16 . Hence, the Ig kappa chains for $2 \mathrm{~L}$ cells were $1.4 \times$ higher than $0 \mathrm{~L}$ cells.

\section{Discussion and Conclusion}

Here we describe four novel results on the effects of lucanthone on 
human Burkitt lymphoma cells. Surviving cultures after two consecutive $20 \mathrm{~h}$ treatments with $8 \mu \mathrm{M}$ lucanthone (2L cells) exhibited enhanced cell content of IgG relative to IgM content. The $2 \mathrm{~L}$ survivors contained enhanced levels of AID. They were much more resistant to challenge by further lucanthone treatments, as determined by clonogenic assays. Mass spectrometry determinations on secreted Ig suggest reduced IgM related proteins and increased IgG related proteins, consistent with these results.

These results show that CRL-1647 Burkitt lymphoma cells which survived the exposure to $8 \mu \mathrm{M}$ lucanthone contained relatively more $\mathrm{IgG}$ than unexposed cells. Moreover, this was a stable feature, expressed in progeny of a single cell which had been cultured over many generations.

Was the enhancement because of selection and proliferation of a pre-existing minor population or induction of a new character in the survivors?

Lucanthone survivors expressed deoxycytidine deaminase (Figures 5 and 6). This enzyme is an essential feature of CSR; its presence in the lucanthone survivors is consistent with their enhanced elaboration of IgG. The relatively small amount of IgG contained in CRL-1647 cells prior to lucanthone exposure (0L cells) suggests small amounts of AID activity. If AID provided survival value to some cells, then this population would be expanded, possibly accounting for the results described here.

Studies on the elaboration of IgG messenger RNA and on the schedule of DNA rearrangements in lucanthone treated cells are of interest but are beyond the scope of this initial report and would involve 4 different m RNA's. Recent studies have implicated hn RNP's as cofactors for AID [18]. Their role, if any, in lucanthone's effects need further consideration. Finally, the roles of selection or induction of IgG enhancement warrants further study, perhaps by fluctuation tests.

Overall, results here demonstrated that lucanthone treatments of Burkitt's lymphoma cells (0L) produced progeny cells (2L) which contained 5 fold more IgG and AID than the parent cell line. IgM was still the predominant Ig species. So far, we have not found enhanced release of IgG related $80 \mathrm{kDa}$ species from $2 \mathrm{~L}$ cells (Figure 8). Both $0 \mathrm{~L}$ cells and 2L cells continuously release this material over many hours.

We cannot yet account for the large differences in the content of $80 \mathrm{kDa}$ Ig's in 2000 fold concentrated supernatants from $0 \mathrm{~L}$ and $2 \mathrm{~L}$ cell cultures (Figure 7), in contrast to little or no difference in $80 \mathrm{kDa}$ Ig's from freshly harvested un-concentrated $0 \mathrm{~L}$ and $2 \mathrm{~L}$ cell supernatants (Figure 8). The isolation from gels and the concentration process, which were needed for mass spectrometry analyses, might to be responsible for differences in amounts of $80 \mathrm{kDa}$ and $25 \mathrm{kDa}$ Ig's after preparation for mass spectrometry. We have found a small increase in IgG related $26 \mathrm{kDa}$ Ig from the $2 \mathrm{~L}$ cells, but this must be confirmed and is not yet certain. Secretion of Ig has been noted in CHO cells and human leukemic cells [19-21].

The full identity of the secreted Ig species remains to be established. Do they attach specifically to antigens? What might be the effect of these secreted immunospecies on the immune response of Burkitt lymphoma patients if their lymphoma cells also secrete them?

Overall, two mechanisms which might account for the increased IgG in these Burkitt's lymphoma cells after treatment with lucanthone. Increased cell content of AID, by a mechanism presently unknown, might have stimulated class switching. But interference with orientation specific joining [22,23] by inhibition of topoisomerase II [6] should also be considered. Perhaps one orientation was favored by inhibition of DNA strand orientation [22,23].

Recently Kanu, et al. found increased APOBEC 3 cytidine deaminases (related to AID) in cancer cells after treatment with several chemotherapeutic agents [24], in general agreement with results of increased AID cytidine deaminase described in this report.

\section{Grant Support}

This work was supported by the Rome Sisters Foundation for Cancer Research, by Grants to R. Bases.

\section{Author Contributions}

Conception and design: R. Bases, Rukmani Lekhraj; IgG and IgM and AID assays: R. Bases; Isotype determinations: Xudong Tang; Flow cytometry measurements of cell surface Ig: Jinghang Zhang. AID measurements: Zhi Duan Mass Spectrometry: Jennifer Aguilan, Edward Nieves

\section{References}

1. Ramiro R, San-Martin BR, McBride K, Jankovic M, Barreto V, et al. (2007) The role of activation-induced deaminase in antibody diversification and chromosome translocations. Adv Immunol 94: 75-107.

2. Muramatsu M, Kinoshita K, Fagarasan S, Yamada I, Shinkai Y, et al. (2000) Class switch recombination and hypermutation require activation-induced cytidine deaminase (AID), a potential RNA editing enzyme. Cell 102: 553-563.

3. Revy P, Muto T, Levy Y, Geissmann F, Plebani A, et al. (2000) Activationinduced cytidine deaminase (AID) deficiency causes the autosomal recessive form of the hyper-IgM syndrome (HIGM2). Cell 102: 565-575.

4. Fernandez D, Ortiz M, Rodriquez L, Garcia A, Martinez D, et al. (2013) The proto-oncogene c-myc regulates antibody secretion and ig class switch recombination. J Immunol 190: 6135-6144.

5. Brar S, Sacho E, Tessmer I, Croteau D, Erie D, et al. (2008) Activation-Induced deaminase, AID, is catalytically active as a monomer on single stranded DNA. DNA Repair 7: 77-87.

6. Bases RE, Mendez F (1997) Topoisomerase inhibition by lucanthone, an adjuvant in radiation therapy. Int J Radiat Oncol Biol Phys 37: 1133-1137.

7. Mendez F, Goldman J, Bases R (2002) Abasic sites in DNA of HeLa cells induced by lucanthone. Cancer Invest 20: 983-991.

8. Bases R, Mendez F, Elequin F, Liebeskind D, Kozin A, et al. (1978) Early steps in mutagenesis by hycanthone. Cancer Res 38: 781-786.

9. Sabouri S, Kobayashi M, Begum NA, Xu J, Hirota K, et al. (2014) C-termina region of activation-induced cytidine deaminase (AID) is required for efficient class switch recombination and gene conversion. Proc Natl Acad Sci USA 111: 2253-2258

10. Shivarov V, Shinkura R, Honjo T (2008) Dissociation of in vitro DNA deamination activity and physiological functions of AID mutants. Proc Natl Acad Sci USA 105: 15866- 15871.

11. Bases R (1970) Enhancement of x-ray damage in HeLa cells by exposure to lucanthone (Miracil D) following radiation. Cancer Res 30: 2007-2011.

12. Blair DM (1958) Lucanthone hydrochloride; a review. Bull World Health Organ 18: $989-1010$.

13. Del Rowe JD, Bello J, Mitnick R, Sood B, Filippi C, et al. (1999) Accelerated regression of brain metastases in patients receiving whole brain radiation and the topoisomerase II inhibitor, lucanthone. Int J Radiat Oncol Biol Phys 43 89-93.

14. Bases $R$ (2006) Heat shock protein 70 enhanced deoxyribonucleic acid base excision repair in human leukemic cells after ionizing radiation. Cell Stress Chaperones 11: 240-249.

15. Bradford MM (1976) A rapid and sensitive method for the quantitation of microgram quantities of protein utilizing the principle of protein-dye binding Anal Biochem 72: 248-254.

16. Bases R (2011) Heat shock protein 70 (Hsp70)-stimulated deoxycytidine deaminases from a human lymphoma cell but not the activation-induced cytidine deaminase (AID) from Ramos 6.4 human Burkitt's lymphoma cells. Cell Stress Chaperones 16: 91-96. 
Citation: Bases R, Lekhraj R, Tang X, Zhang J, Duan Z, et al. (2017) Enhanced Content of IgG in Burkitt's Lymphoma Cells after Treatment with the Topoisomerase II Inhibitor, Lucanthone. J Bioanal Biomed 9: 186-193. doi:10.4172/1948-593X.1000176

17. Letourneau PC (1975) Possible Roles for cell-to-substratum adhesion in neural morphogenesis. Dev Biol 44: 71-91.

18. Hu W, Begum NA, Mondal S, Stanlie A, Honjo T (2015) Identification of DNA cleavage- and recombination-specific hnRNP cofactors for activation-induced cytidine deaminase. Proc Natl Acad Sci U S A 112: 5791-5796.

19. Tait AS, Hogwood CE, Smales CM, Bracewell DG (2012) Host cell protein dynamics in the supernatant of amAb producing cell line. Biotechnol Bioeng 109: 971-982.

20. Premkumar E, Singer PA, Williamson AR (1975) A human lymphoid cell line secreting immunoglobulin $G$ and retaining immunoglobulin $M$ in the plasma membrane. Cell 5: 87-92.
21. Nilsson K, Ghetie V, Sjöquist J (1975) A human lymphoid cell line with an IgGlike membrane component. Eur J Immunol 5: 518-526.

22. Dong J, Panchakshari RA, Zhang T, Zhang Y, Hu J, et al. (2015) OrientationSpecific joining of AID initiated DNA breaks promotes antibody class switching Nature 525: 134-139.

23. Di Noia JM (2015) Molecular biology: Unequal opportunity during class switching. Nature 525: 44-45.

24. Kanu N, Cerone MA, Goh G, Zalmas, LP, Dietzen M, et al. (2016) DNA replication stress mediates APOBEC 3 family mutagenesis in breast cancer. Genome Biol 17: 185-200. 